\title{
Afforestation With Tropical N-Fixing Species in The Brazilian Atlantic Rainforest: Carbon and Nitrogen in The Soil Profile
}

David Pessanha Siqueira ( $\nabla$ dps@pq.uenf.br)

Universidade Estadual do Norte Fluminense Darcy Ribeiro https://orcid.org/0000-0002-0756-0153

Emanuela Forestieri Gama-Rodrigues

Universidade Estadual do Norte Fluminense Darcy Ribeiro

Marcos Vinícius Winckler Caldeira

Universidade Federal do Espírito Santo

Carlos Eduardo Rezende

Universidade Estadual do Norte Fluminense Darcy Ribeiro

Claudio Roberto Marciano

Universidade Estadual do Norte Fluminense Darcy Ribeiro

Deborah Guerra Barroso

Universidade Estadual do Norte Fluminense Darcy Ribeiro

\section{Research Article}

Keywords: Soil organic matter, soil total nitrogen, isotope fractionation, carbon sequestration

Posted Date: June 11th, 2021

DOl: https://doi.org/10.21203/rs.3.rs-594747/v1

License: (9) (i) This work is licensed under a Creative Commons Attribution 4.0 International License. Read Full License 


\section{Abstract}

\section{Aims}

Atlantic Rainforest biome is one of the most threatened in the world by deforestation where afforestation programs are urgently needed. $\mathrm{N}$-fixing species should be prioritized in re-establishing forest covers as they can enhance soil $\mathrm{C}$ and $\mathrm{N}$ and stimulate cycling of other nutrients. Yet, tropical ecosystems play a key role in global warming and remain underestimated in the global biogeochemical balances. We aimed to investigate the effects of tropical $\mathrm{N}$-fixing species on soil $\mathrm{C}$ and $\mathrm{N}$ pools after pasture conversion

\section{Methods}

We selected: Plathymenia reticulata, Hymenaea courbaril, and Centrolobium tomentosum 27-year-old monospecific stands. We evaluated soil organic carbon (SOC), nitrogen (STN), and the natural abundance of ${ }^{13} \mathrm{C}$ and ${ }^{15} \mathrm{~N}$ in the soil profile up to $100 \mathrm{~cm}$ depth.

\section{Results}

SOC was higher for $P$. reticulata, but an opposite pattern was observed when combining only soil layers up to $30 \mathrm{~cm}$ soil depth. Meanwhile, STN was similar across species and $d^{15} \mathrm{~N}$ values showed enrichment at intermediate soil layers indicating ${ }^{14} \mathrm{~N}$ gaseous loss. Most of the SOC originated from the planted trees rather than the former pasture, except beneath $C$. tomentosum where $\mathrm{C}_{4}$ derived $\mathrm{C}$ is decreasing at a slower rate.

\section{Conclusion}

This study presents novel insights in the understanding of tropical $\mathrm{N}$-fixing species effects on soil $\mathrm{C}$ and $\mathrm{N}$ where specific-species traits appear to mediate SOC retention to the mineral soil rather than the $\mathrm{N}$-fixing ability per se.

\section{Introduction}

The Atlantic Rainforest biome has high species diversity and a high level of endemism and it has been identified as one of the world's hotspots of biodiversity (Myers et al. 2000). Despite its ecological relevance, the biome is one of the most threatened by deforestation on earth where only $9-12 \%$ of the original vegetation remains existing in small, isolated, and unprotected fragments (Ribeiro et al. 2009; SOS Mata Atlântica 2020).

The main causes of the Atlantic Rainforest fragmentation are clearing for crops, timber, animal grazing, firewood, and urbanization. Given this scenario, forest plantations to recover the biome are urgently needed and, if well managed, revegetation of degraded sites can also contribute to meet market demand of timber and non-timber products, therefore, reducing illegal logging (Barroso et al. 2018). 
In the context of the Atlantic Rainforest's species diversity, the experience with its species and their interaction with soil fertility is limited, and knowledge of tropical $\mathrm{N}$-fixing species is even scarcer, recognized as a current gap in the literature (Mayer et al. 2020). By biological nitrogen fixation, $\mathrm{N}$-fixers can associate with bacteria and convert atmospheric $\mathrm{N}_{2}$ to ammonia $\left(\mathrm{NH}_{3}\right)$. The continuous $\mathrm{N}$ accretion to the soil system tends to stimulate cycling of other nutrients (Chaer et al. 2011; Mendes et al. 2021).

More specifically, $\mathrm{N}$-fixing tree species have been reported to exert a key role in enhancing terrestrial carbon (C) concentration and stocks when compared to non-N-fixing species (Luo et al. 2004; Forrester et al. 2013; Mayer et al. 2020) with $\mathrm{N}$ inputs increasing $+11.8 \%$ mineral soil $\mathrm{C}$ storage as reported by Nave et al. (2009) in a meta-analysis only including temperate forests. At a global scale, the higher soil C even beneath tropical $\mathrm{N}$-fixing tree species was confirmed by Peng et al. (2020). The greater accumulation of fresh $\mathrm{C}$ plus the retention of old soil $\mathrm{C}$ are the main assumptions to explain the increased soil $\mathrm{C}$ under $\mathrm{N}$ fixing tree species (Resh et al. 2002), however, the underlying processes remain elusive (Peng et al. 2020).

$\mathrm{N}$-fixing tree species has been prioritized in afforestation programs as the improvements for soil fertility will be helpful for stand productivity and where more demanding trees can grow (Chaer et al. 2011; Forrester et al. 2013; Mayer et al. 2020). Shifting cultivation e.g. pasture to tropical $\mathrm{N}$-fixing species can restore $\mathrm{C}$ and $\mathrm{N}$ to the levels found in the soil under native vegetation in a short period of time (Macedo et al. 2008; Chaer et al. 2011), since new $C$ and $N$ inputs will occur through above and belowground plant litter (Hoogmoed et al. 2014b; Vicente et al. 2016; Ngaba et al. 2020). However, C sequestration, as well as $\mathrm{N}$ retention and their vertical distribution in the soil, will be mediated by specific functional traits of each species such as litter productivity and litter chemical composition (Thomas and Prescott 2000; Vesterdal et al. 2008; Li et al. 2020; Peng et al. 2020).

To better understand the fate of litter $\mathrm{C}$ and $\mathrm{N}$ and their transformation and pools in the soil profile after land-use changes, stable isotopic fractionation has been applied as a powerful tool (Hobbie and Ouimette 2009; Liu et al. 2018b; Paul et al. 2019). The technique is also effective to track land-use changes' effects on soil organic matter (SOM) origin (Conen et al. 2008; Vicente et al. 2016; Carvalho et al. 2017).

Apart from the soil fertility improvement, soil C storage in the soil profile has a particular contribution for mitigating greenhouse gas fluxes acting as a great sink or source within the climate change context. Its relevance is due to large amounts (approximately $2344 \mathrm{Gt}$ ) of organic C stored in the soil globally (Stockmann et al. 2013) with a large contribution from forest ecosystems (Pan et al. 2011) where deforestation of tropical areas have a significant impact on the global C cycle (Silver et al. 2000; Villela et al. 2012).

Evidence of litterfall $\mathrm{N}$ association with soil $\mathrm{N}$ status was already observed under different European common gardens (Vesterdal et al. 2008), and in accordance with the meta-analysis performed by Zheng et al. (2021), an average of $24 \%$ of the $C$ and $58 \%$ of the $\mathrm{N}$ lost from litter were recovered to the soil 
regardless of experimental conditions. Yet, the authors concluded that proportionally higher $\mathrm{C}$ and $\mathrm{N}$ were transferred to the soil from slowly than rapidly decomposing litters.

A previous study showed that two even-aged tropical $\mathrm{N}$-fixing species returned different amounts of $\mathrm{C}$ and $\mathrm{N}$ via leaf litter where Plathymenia reticulata had higher $\mathrm{C}$ and $\mathrm{N}$ than Hymenaea courbaril with similar decay rates (Siqueira et al. in press). Thus, given these differences, a first question arose: Does $P$. reticulata have enhanced soil $\mathrm{C}$ and $\mathrm{N}$ than $\mathrm{H}$. courbaril? To test that and to have a greater overview of tropical $\mathrm{N}$-fixing species we also included in the study Centrolobium tomentosum (with similar leaf litter $\mathrm{C}$ and $\mathrm{N}$ contents to $\mathrm{H}$. courbari). This study aimed to answer a second question: Did tropical $\mathrm{N}$-fixing species with different leaf litter $\mathrm{C}$ and $\mathrm{N}$ contents recover $\mathrm{C}$ and $\mathrm{N}$ to the soil consistently with litter contents? The quantification considers $0-30 \mathrm{~cm}$ soil grouped individually and the soil profile up to 100 $\mathrm{cm}$.

The three species are located at the same study site that was previously a pasture where single monospecific forest stands were planted 27 years ago. Due to the historical land-use change back in time, we targeted our third question based on ${ }^{13} \mathrm{C}$ isotope labeling: How much did the pasture conversion to 27-year-old tropical $\mathrm{N}$-fixing plantations change the origin of the current SOM?

Lastly, our fourth question was based on the well-established knowledge that tropical sites are not Nlimited (Martinelli et al. 1999) and might have ${ }^{15} \mathrm{~N}$-enriched $\mathrm{N}$ in the soil mainly due to gaseous ${ }^{14} \mathrm{~N}$ differential loss (Houlton et al. 2006; Hobbie and Ouimette 2009; Peri et al. 2012). Do tropical N-fixing species have similar patterns regarding ${ }^{15} \mathrm{~N}$ enrichment/depletion in the soil profile?

The first objective related to the question 1 and 2 was quantification of SOC beneath $\mathrm{N}$-fixing species with different leaf litter $C$ and $N$ contents individually to a layer of 0-30 and also up to $100 \mathrm{~cm}$. The second objective related to question 3 was quantification of the contribution of $\mathrm{C}_{3}$-derived $\mathrm{C}$ and $\mathrm{C}_{4}$-derived $\mathrm{C}$ after pasture conversion to tropical $\mathrm{N}$-fixing tree plantations. Finally, the third objective related to the fourth question was to understand vertical ${ }^{15} \mathrm{~N}$ fluctuation among tropical $\mathrm{N}$-fixing tree plantations after land-use change.

\section{Materials And Methods}

\subsection{Site descriptions}

The study was carried out in the mountain region of Rio de Janeiro, Brazil, within the municipal limits of Trajano de Moraes ( $22^{\circ} 04^{\prime} 32^{\prime \prime} \mathrm{S} 42^{\circ} 03^{\prime} 51^{\prime \prime} \mathrm{W}$ ) in the Atlantic Rainforest biome domain. The average temperature is between 18 and $24^{\circ} \mathrm{C}$ and annual precipitation of $1100 \mathrm{~mm}$. The altitude is $700 \mathrm{~m}$ above sea level. The soil is a Typic Haplohumults (Soil Survey Staff, 2014) with low activity clay.

The site was previously forest followed by a pasture (no information for how long) that had experienced erosion and unplanned fires. In 1992, Atlantic Forest species were planted to recover the area. The 
plantation was done as minimum tillage, with manual weeding, $0.40 \times 0.40 \times 0.40 \mathrm{~m}$ planting pits, use of cattle manure (10L per pit), and 10-28-06 NPK fertilizer (100 g per plant) at planting time.

A total of 49 seedlings of each tree species were planted in single plots and spaced at $3 \times 3$ $\mathrm{m}$. Surrounding the plots, there are equidistant tree plantations and a natural forest fragment that could provide seeds for understory regeneration. Additionally, floristic inventory and diversity assessments did not display presence of grasses in any of the forest plots (unpublished data) indicating that the forest stands are composed mainly of $\mathrm{C}_{3}$ vegetation.

We selected three forest species belonging to the Fabaceae family: Plathymenia reticulata Benth, Hymenaea courbaril Linneaeus, and Centrolobium tomentosum Guillem ex Benth. The species had survival rate of ${ }^{3} 90 \%$, average height ranging from 13 to $15 \mathrm{~m}$ and the diameter at breast height ca. 13 $\mathrm{cm}$ for $H$. courbaril and $C$. tomentosum and $24 \mathrm{~cm}$ for $P$. reticulata (Barroso et al. 2018). The species also have a great environmental and economic interest in timber and non-timber products (Cartaxo et al. 2010; Della Torre et al. 2011; Erbano and Duarte 2012; Calderón-Peralta et al. 2017; Gombeau et al. 2019; Siqueira et al. 2021).

Yet, a 50-year-old unfertilized pasture composed of Brachiaria decumbens and a Secondary Forest (upper canopy logged approximately 35 years ago) were considered as references for $\mathrm{C}_{4}$ and $\mathrm{C}_{3}$ vegetation covers, respectively, and used for calculations with soil ${ }^{13} \mathrm{C}$ fractionation data beneath the aforementioned species. These areas are also located in the Atlantic Rainforest biome ( $21^{\circ} 07^{\prime} 50^{\prime \prime} \mathrm{S} 42^{\circ}$ 21 ' 59 " W) and were evaluated by Vicente et al., (2016).

\subsection{Soil sampling and analysis}

Mineral soil was sampled in the central planting rows between trees (approximately $40 \mathrm{~cm}$ from the trunk basis) in the following layers: $0-10 \mathrm{~cm} ; 10-20 \mathrm{~cm} ; 20-30 \mathrm{~cm} ; 30-40 \mathrm{~cm} ; 40-50 \mathrm{~cm} ; 50-75 \mathrm{~cm}$ and 75-100 $\mathrm{cm}$, with four replicates per layer in each forest stand. For soil physical characterization, soil samples from 0-10 and 10-20 cm soil layers were considered individually beneath each forest stand.

However, for soil layers deeper than $20 \mathrm{~cm}$, soil samples were collected from a single trench dug up to $100 \mathrm{~cm}$ and we considered them representative for all the forest stands given the soil similarity beneath them. Samples were air-dried and sieved ( $2 \mathrm{~mm}$ sieve) for soil particle size determination. The volumetric ring method was used to determine soil bulk density (Embrapa 1997). The soil physical characterization is described in Table 1. 
Table 1. Particle size fractions and soil bulk density up to $100 \mathrm{~cm}$ under different tropical $\mathrm{N}$-fixing tree species in the Southeast Brazil

Soil layer Particle size fraction (\%) and bulk density - Forest species

(cm) BD- $\left(\mathrm{g} \mathrm{cm}^{-3}\right)$

C.tomentosum $H$. P. courbaril reticulata

$\begin{aligned} 0-10 & \text { Sand } \\ & \text { Silt } \\ & \text { Clay }\end{aligned}$

45

40

38

$\mathrm{BD}$

23

24

22

lay

32

36

40

\begin{tabular}{ll} 
& BD \\
\hline $10-20$ & Sand \\
& Silt \\
& Clay
\end{tabular}

1.130

1.202

1.010

Sand

45

42

32

Silt

14

13

10

Clay

36

44

57

BD

20-30

Sand

1.320

1.320

1.201

Silt

Silt

32

32

32

10

10

10

BD

30-40

BD

40-50

\begin{tabular}{|c|c|c|c|c|}
\hline & $\mathrm{BD}$ & 1.105 & 1.105 & 1.105 \\
\hline \multirow[t]{4}{*}{$50-75$} & Sand & 26 & 26 & 26 \\
\hline & Silt & 6.7 & 6.7 & 6.7 \\
\hline & Clay & 66 & 66 & 66 \\
\hline & $\mathrm{BD}$ & 1.124 & 1.124 & 1.124 \\
\hline $75-100$ & Sand & 26 & 26 & 26 \\
\hline
\end{tabular}




\begin{tabular}{lllll} 
Silt & 5.9 & 5.9 & 5.9 \\
\hline Clay & 68 & 68 & 68 \\
\hline BD & 1.121 & 1.121 & 1.121
\end{tabular}

The soil organic carbon (SOC) and total nitrogen (STN) contents were determined by dry combustion in an automated elemental analyzer (CHNS/O analyzer). Then, considering soil layer thickness, the soil bulk density at each layer was multiplied by SOC or STN to calculate SOC and STN stocks stored in the soil profile, expressed in $\mathrm{Mg} \mathrm{ha}^{-1}$. SOC was then corrected by the clay content of the soil as the organic matter fluctuations are related to soil texture (Moraes et al. 1996).

The natural abundance of ${ }^{13} \mathrm{C}$ and ${ }^{15} \mathrm{~N}$ were determined using the Isotope Ratio Mass Spectrometer Delta V Advantage (IRMS - Thermo Scientific) coupled with Organic Elemental Analyzer (Thermo Scientific), and the results were expressed in (\%o) relative to the Pee Dee Belemnita (PDB) and atmospheric $\mathrm{N}_{2}$ International standards, respectively, calculated using the following equation:

$d^{13} \mathrm{C}$ or $d^{15} \mathrm{~N}=\left(\mathrm{R}_{\text {sample }}-\mathrm{R}_{\text {reference }}\right) / \mathrm{R}_{\text {reference }}$

where $R_{\text {sample }}={ }^{13} \mathrm{C} /{ }^{12} \mathrm{C}$ or ${ }^{15} \mathrm{~N} /{ }^{14} \mathrm{~N}$ ratio of the sample and $\mathrm{R}_{\text {reference }}={ }^{13} \mathrm{C} /{ }^{12} \mathrm{C}$ or ${ }^{15} \mathrm{~N} /{ }^{14} \mathrm{~N}$ ratio of the reference samples

To distinguish the proportion of $\mathrm{C}$ derived from the previous pasture $\left(\mathrm{C}_{4}\right.$ vegetation $)$ and from the current forest stands $\left(C_{3}\right.$ vegetation) we used the equation proposed by Vitorello et al. (1989):

$\% C-C_{4}=\left[\left(d-d_{a}\right)-\left(d_{p}-d_{a}\right)\right] * 100$,

where $d=$ natural $d^{13} \mathrm{C}$ abundance in the samples; $d_{a}=$ natural $d^{13} \mathrm{C}$ abundance in the soil samples without $C_{4}$ plant residue (Secondary forest from Vicente et al. (2016) used as reference); $d_{p}=$ natural $d^{13} C$ abundance of the pasture plant material (-12.65\%o).

Lastly, the following equation was used to obtain the $\%$ of the $\mathrm{C}_{3}$ carbon:

$\% \mathrm{C}-\mathrm{C}_{3}=100-\% \mathrm{C}-\mathrm{C}_{4}$

\subsection{Data analysis}

Considering the study site has no statistical design and no fill requirements for parametric analysis, our data was also submitted to descriptive analysis and comparison by Confidence Interval $(p<0.05)$ by Student's T-test (Rmisc package, Hope 2013) through R software (R Core Team 2019). The comparison was based on the overlapping of the Confidence Interval limits (or lack thereof), which allows to differ means with high statistical support (McGill et al. 1978). 
Principal component analysis (PCA) was conducted using soil data $(0-30 \mathrm{~cm}$ where the historical landuse change is more likely to be noticed) to evaluate a possible grouping pattern among species. For this analysis, data were standardized through z-scale transformation to avoid scale influence and plotted using ggbiplot package (Vu 2011).

Unreplicated tree stands with pseudo-replication within each species is a limitation of the present study, but frequent in forestry experiments, e.g. Lima et al. (2006); Vesterdal et al. (2002); Vicente et al. (2016). To compare tree species effects on soil $\mathrm{C}$ and $\mathrm{N}$ storage, an experimental site that limits influences from age, climate, and soil type has a crucial role but it is still rare (Oostra et al. 2006; Vesterdal et al. 2008). Given the uniqueness of these common gardens, they should not be neglected. Yet, differences in the topsoil properties among species located at the same study site were previously described by Barroso et al. (2018) also through confidence intervals which validates our analysis.

\section{Results}

\subsection{Soil organic carbon (SOC) and nitrogen (STN) storage}

The SOC in the 0-100 $\mathrm{cm}$ soil layer was higher for $P$. reticulata $\left(214 \mathrm{Mg} \mathrm{ha}^{-1}\right)$ than $C$. tomentosum (171 $\mathrm{Mg} \mathrm{ha}^{-1}$ ) but not different from $\mathrm{H}$. courbaril $\left(202 \mathrm{Mg} \mathrm{ha}^{-1}\right)$. Conversely, regarding the 0-30 $\mathrm{cm}$ soil layer an opposite pattern was observed, but not statistically significant, with SOC showing the lowest value for $P$. reticulata with $84 \mathrm{Mg} \mathrm{ha}^{-1}$ and highest for $H$. courbaril with $107 \mathrm{Mg} \mathrm{ha}^{-1}$ (Fig.1). The STN in the 0-100 cm soil layer was similar among species ( $p=0.16)$ with an average of $16 \mathrm{Mg} \mathrm{ha}^{-1}$ and $44 \%\left(7 \mathrm{Mg} \mathrm{ha}^{-1}\right)$ of the STN budget is accumulated at the top $0-30 \mathrm{~cm}$ soil layer where no differences among species were found as well (Fig.1).

A similar pattern, but without statistically significant differences among species, was observed for SOC and STN at the individual depth intervals in the soil profile, with higher values in the uppermost soil layers followed by a slight decrease at intermediate layers and increases in the bottommost wider layers (Fig. 2).

\subsection{Soil ${ }^{13} \mathrm{C}$ and ${ }^{15} \mathrm{~N}$ abundance fluctuations}

The natural abundance of the ${ }^{13} \mathrm{C}$ was similar among forest stands with relative ${ }^{13} \mathrm{C}$-depleted $\mathrm{C}$, not far from the Secondary Forest considered as a reference for $\mathrm{C}_{3}$ vegetation. However, $C$. tomentosum had ${ }^{13} \mathrm{C}$ enriched $\mathrm{C}$, closer to the Pasture, reference for $\mathrm{C}_{4}$ vegetation, than the other species (Fig. 3a). The soil $d^{15} \mathrm{~N}$ values did not follow the same trajectories as $\mathrm{d}^{13} \mathrm{C}$ values with soil depth.

We observed relatively ${ }^{15} \mathrm{~N}$-depleted $\mathrm{N}$ in the upper soil layers, but $\mathrm{d}^{15} \mathrm{~N}$ values became more ${ }^{15} \mathrm{~N}$-enriched with depth. This pattern did not follow until deeper layers but only at intermediate depths. (Fig. 3b). Vertical changes in $\mathrm{d}^{15} \mathrm{~N}$ values were around $\sim 2 \%$ o under $P$. reticulata, approximately two times more than $C$. tomentosum and $H$. courbaril stands. 
The $\mathrm{d}^{13} \mathrm{C}$ values showed higher contribution of $\mathrm{C}_{4}$ vegetation under $C$. tomentosum even in the upper soil layers (0-10, 10-20, and 20-30 cm) when compared to $H$. courbaril and P. reticulata (Fig. 4).

Nevertheless, the accumulated $C_{-} C_{3}$ at 0-10 cm layer was lower to the Secondary Forest $\left(28.5 \mathrm{Mg} \mathrm{ha}^{-1}\right)$ when compared to the $\mathrm{N}$-fixing species where the values ranged from $33.8 \mathrm{Mg} \mathrm{ha}^{-1}$ to $46.1 \mathrm{Mg} \mathrm{ha}^{-1}$, but higher than $P$. reticulata at $10-20 \mathrm{~cm}$ soil layer.

The PCA (91.7\% explanation of the data variability) showed a direct association between soil $\mathrm{C}$ and $\mathrm{N}$ stocks, and a negative correlation to $\mathrm{PC} 1$. The isotopic fractionation of ${ }^{13} \mathrm{C}$ and ${ }^{15} \mathrm{~N}$ is indirectly correlated to soil $\mathrm{C}: \mathrm{N}$ ratio indicated by the arrows in opposite directions (Fig. 5). The species were organized in different groups, where $C$. tomentosum is more associated with $\mathrm{d}^{13} \mathrm{C}$ and $\mathrm{d}^{15} \mathrm{~N}$ fluctuations and $P$. reticulata and $H$. courbaril associated together with soil $\mathrm{C}$ and $\mathrm{N}$ stocks and $\mathrm{C}: \mathrm{N}$ ratio.

\section{Discussion}

4.1 Soil organic carbon (SOC) and total nitrogen (STN) storage

Soil $\mathrm{C}$ stock beneath a secondary forest located at the same biome (168 $\mathrm{Mg} \mathrm{ha}^{-1}$ up to $1 \mathrm{~m}$ depth) was similar to $C$. tomentosum but lower than $H$. courbaril and $P$. reticulata. Disturbances occurred approximately 30 years ago in the secondary forest which might have decreased above and below ground plant litter inputs as well as the decomposition dynamics (Vicente et al. 2016). However, given the time after pasture conversion to the $\mathrm{N}$-fixing trees (27 years), we assumed that comparisons among them are worth it.

The higher SOC stock was observed under $P$. reticulata stand (up to $1 \mathrm{~m}$ depth) but considering only the upper soil layers $(0-30 \mathrm{~cm})$ an opposite pattern was shown. The $C$ contribution located deep down the soil profile is unlikely to be on account of the planted $\mathrm{N}$-fixing tree species as changes on soil $\mathrm{C}$ are typically distinguishable in the forest floor and top mineral soil layers (Vesterdal et al. 2008; Guillaume et al. 2015; $\mathrm{Xu}$ et al. 2021). Due to the relatively short time after pasture conversion to the $\mathrm{N}$-fixing stands, the soil $\mathrm{C}$ and $\mathrm{N}$ in the subsoil are probably derived from the forest vegetation even before the pasture. Therefore, to discuss $\mathrm{N}$-fixing species effects on soil $\mathrm{C}$ and $\mathrm{N}$ we will limit the evaluated soil layer to $30 \mathrm{~cm}$ depth.

Comparing to a deforested area (35.4 $\mathrm{Mg} \mathrm{C} \mathrm{ha}^{-1}$ and 3.0 $\mathrm{Mg} \mathrm{N} \mathrm{h}^{-1}$ ) and a secondary forest with few signs of anthropic interference ( $58.3 \mathrm{Mg} \mathrm{C}$ and $5.4 \mathrm{Mg} \mathrm{N}$ ) in the $0-30 \mathrm{~cm}$ soil layer, both located within the Atlantic Forest domain, (Macedo et al. 2008), the soil beneath the $\mathrm{N}$-fixing species had higher values of SOC and STN.

It is well known that $\mathrm{N}$-fixing species enhance soil $\mathrm{C}$ stocks when compared to non-N-fixing (Resh et al. 2002; Chaer et al. 2011; Hoogmoed et al. 2014b). Greater retention of old $C$ and higher inputs of new soil $\mathrm{C}$ have been attributed to the $\mathrm{N}$-fixing trees to explain this fact (Resh et al. 2002; Luo et al. 2004). Keeping this in mind, $P$. reticulata had the highest $\mathrm{C}$ and $\mathrm{N}$ contents returned via leaf litter (Siqueira et al. in press), the lowest retention of old $\mathrm{C}$ derived from the previous pasture (Fig. 4), and the lowest SOC stock in the 0- 
$30 \mathrm{~cm}$ soil layer. On the other hand, $C$. tomentosum had lower leaf litter $C$ content, higher retention of old $\mathrm{C}$ derived from the previous pasture (at a depth of 0-30 $\mathrm{cm}$ ) and higher SOC stock (similar to $\mathrm{H}$. courbaril stand) in the same combined soil layers.

Pairing with a 35-year-old rubber plantation (non-N-fixer) located within similar edaphic and climatic

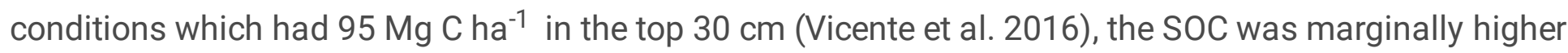
than $P$. reticulata, similar to $C$.tomentosum, and lower than $H$.courbaril. It suggests that tropical $\mathrm{N}$-fixing species depend more on other species-specific traits of each species such as openness canopy, litter productivity, chemical composition and structure as non-N-fixers can eventually reach similar SOC.

Different $\mathrm{C}$ and $\mathrm{N}$ addition to the soil was observed by two $\mathrm{N}$-fixing tree species in a temperate climate (south-eastern Australia), and the authors also attributed to specific traits of each species and changes on microbial community composition (Hoogmoed et al. 2014a). Similar results were found by Wang et al. (2010) also comparing two $\mathrm{N}$-fixing species at the top $5 \mathrm{~cm}$ soil layer. Due to the differences on $\mathrm{C}$ (and $\mathrm{C}$ recalcitrance), $\mathrm{N}$, and $\mathrm{P}$ leaf litter across our species (Siqueira et al. in press), it is expected that decomposer community will differ and/or the microbial activity, as described by the aforementioned authors and it warrants further investigations.

Despite its higher leaf litter $\mathrm{C}$ content, another possible explanation for the lower SOC in the 0-30 cm soil layer under P.reticulata is that the leaf litter had a more recalcitrant litter with high lignin concentration (Siqueira et al. in press) which might have lowered the substrate use efficiency by microbes and therefore soil C (Marschner et al. 2008; Cotrufo et al. 2013). Apart from that, P.reticulata had higher growth rates (Barroso et al. 2018) and the uptake of nutrients might have reduced soil $\mathrm{C}$ and $\mathrm{N}$ at a layer of 0-30 cm as well (Hoogmoed et al. 2014a).

Differences in the mineral soil $(0-30 \mathrm{~cm})$ beneath six European tree species (non-N-fixers) were observed for $\mathrm{N}$ stock but not for $\mathrm{C}$ stock, attributed to litterfall $\mathrm{N}$ status. Moreover, $\mathrm{C}$ and $\mathrm{N}$ may also be incorporated into the mineral soil at a higher rate in some tree species due to different root distribution in the soil profile (Vesterdal et al. 2008). We observed an opposite pattern in our study site where differences were found only for $\mathrm{C}$ stocks when combining the same soil layers. It is expected that $\mathrm{N}$-fixing tree species will have higher soil $\mathrm{N}$ as they often have higher $\mathrm{N}$ content in their biomass, litter, and root exudates (Hoogmoed et al. 2014b), however, the literature lacks information on the root architecture and nutrient concentration of our species.

Despite the large differences between $\mathrm{N}$ returned via litterfall, STN was similar across species. STN is most unlikely to be impacted by climatic factors compared to SOC (Xiang et al. 2021). However, substantial $\mathrm{N}$ losses appear to be occurring especially in the soil under $P$. reticulata with greater canopy openness and tendency for higher soil temperatures. Gaseous $\mathrm{N}$ losses frequently happen in $\mathrm{N}$-saturated tropical systems due to soil capacity limitations (Bingham and Cotrufo 2016) as tropical weathered acid soils (Campo and Merino 2016).

4.2 Soil ${ }^{13} \mathrm{C}$ and ${ }^{15} \mathrm{~N}$ abundance variations 
Soil $\mathrm{d}^{13} \mathrm{C}$ values under the $\mathrm{N}$-fixing stands were similar to Brazilian native forests (Dortzbach et al. 2015; Carvalho et al. 2017), Amazon rainforest (Araújo et al. 2011), and Hevea brasiliensis stand at 35 years which was previously a pasture as well (Vicente et al. 2016). However, the soil beneath $C$. tomentosum had enriched $\mathrm{d}^{13} \mathrm{C}$ values (about 1.6\%) in the uppermost $\sim 40 \mathrm{~cm}$ of the soil profile explained by the mixing of fresh and old litter inputs.

It is frequently reported a relatively rapid shift from $\mathrm{C}_{4}$-derived $\mathrm{C}$ to $\mathrm{C}_{3}$-derived $\mathrm{C}$ in tropical regions mainly due to weather conditions where the warm and humid environment accelerates the organic matter decomposition rates mostly in the upper soil layers (Villela et al. 2012; Maggiotto et al. 2014). The soil $\mathrm{C}_{4^{-}}$ derived $\mathrm{C}$ losses are decreasing at a slower rate under $C$. tomentosum than $P$. reticulata and $H$. courbaril in the topsoil layers even though the temperature and humidity were the same. It is supported by the PCA where the ${ }^{13} \mathrm{C}$ soil and ${ }^{15} \mathrm{~N}$ soil arrows were more related to $C$. tomentosum.

Indirectly related to climatic factors, larger canopy densities will have higher rainfall and light interception and hence low soil moisture content and soil temperatures, respectively (Liu et al. 2018; Xiang et al. 2021). The higher canopy openness in P. reticulata stand (Fig. 6) could also justify the lower $\mathrm{C}_{4}$-derived $\mathrm{C}$ due to rapid decomposition rates. However, $C$. tomentosum had the second higher canopy openness, but the slower decomposition rates of the old $\mathrm{C}$.

When $\mathrm{N}$-fixers accumulated relatively more soil $\mathrm{N}$, the soil retains more $\mathrm{C}_{4}$-derived $\mathrm{C}$ (Resh et al. 2002) as higher $\mathrm{N}$ under $\mathrm{N}$-fixing likely shift microbial community towards bacterial dominance and therefore slower organic matter decomposition rates are expected (Hoogmoed et al. 2014a). Indeed, we found a positive correlation between SOC and STN in the $0-30 \mathrm{~cm}$ soil layer across species but the trend is less clear when partitioning $\mathrm{C}_{4}$-derived $\mathrm{C}_{\text {and }} \mathrm{C}_{3}$-derived $\mathrm{C}$ retention.

Concerning ${ }^{15} \mathrm{~N}$ fractionation, the fresh litter is relatively labile compared to organic matter in deeper soil layers and it explains ${ }^{15} \mathrm{~N}$-depleted $\mathrm{N}$ across species in the soil surface (Hobbie and Ouimette 2009; $\mathrm{Ngaba}$ et al. 2019). Likewise, the lower $\mathrm{d}^{15} \mathrm{~N}$ values can also be explained by the $\mathrm{N}$ fixation rates as fixed $\mathrm{N}$ from the atmosphere has values close to zero (Martinelli et al. 1999).

The ${ }^{15} \mathrm{~N}$ enrichment at intermediate depths is a frequent pattern when there is $\mathrm{N}$ losses of ${ }^{14} \mathrm{~N}$ by gaseous nitrification and denitrification, which is common in tropical ecosystems (Houlton et al. 2006; Hobbie and Ouimette 2009; Peri et al. 2012; Nel et al. 2018). Generally, stands with an open N cycle (large pools and fluxes) seem to cause soil ${ }^{15} \mathrm{~N}$ enrichment (Callesen et al. 2013). Yet, nitrification in soils could reduce soil $\mathrm{pH}$ by producing protons in its chemical processes (Wang et al. 2010) and the lowest pH was observed for $P$. reticulata (Barroso et al. 2018), and both facts support our previous assumption.

There is high evidence that species-specific traits such as litter chemical composition and hence microbial community are driving the SOC and STN budgets and organic matter decomposition rates more than weather conditions per se. Furthermore, the productivity and chemical composition of the litter from understory vegetation might have influenced $\mathrm{C}$ and $\mathrm{N}$ cycling beneath the $\mathrm{N}$-fixing plantations but any 
conclusion requires further investigations. Yet, a greater overview of tropical $\mathrm{N}$-fixing tree species effects' on SOC, STN, and isotopic fractionation has to include more species and then be investigated more closely.

\section{Conclusion}

Afforestation with tropical 27-year-old $\mathrm{N}$-fixing tree plantations was able to restore soil $\mathrm{C}$ and $\mathrm{N}$ to similar or even higher rates as found in forest sites after less hostile disturbances. However, the soil beneath $P$. reticulata had enhanced soil $\mathrm{C}$ stored up to $100 \mathrm{~cm}$ depth with no differences for soil $\mathrm{N}$ across species.

Despite larger variations in leaf litter $\mathrm{C}$ and $\mathrm{N}$ contents among species, slight differences were observed for SOC and STN in the topsoil layers. Nevertheless, $C$. tomentosum had a slower decomposition rate of old soil $\mathrm{C}$ (higher $\mathrm{C}_{4}$ - derived $\mathrm{C}$ left). It seems that tropical $\mathrm{N}$-fixing tree species differ in $\mathrm{C}$ sequestration rates within mineral soil.

A similar vertical STN and ${ }^{15} \mathrm{~N}$ distribution in the soil profile was observed across species with a slight tendency towards ${ }^{15} \mathrm{~N}$ enrichment in the soil beneath $P$. reticulata and $C$. tomentosum stands.

Litter quality and productivity seem to be shaping the microbial community and activity differently beneath each species and hence SOC and STN pools, but any conclusion requires further investigations for a greater overview of the role $\mathrm{N}$-fixing tree species on soil $\mathrm{C}$ and $\mathrm{N}$.

\section{Declarations}

\section{Funding}

Conselho Nacional de Desenvolvimento Científico e Tecnológico (Grant number 141513/2017-9); Fundação Carlos Chagas Filho de Amparo à Pesquisa do Estado do Rio de Janeiro (Grant numbers E26/200.84/2019 and E-26/ 210.064 /2018); Coordenação de Aperfeiçoamento de Pessoal de Ensino Superior (Grant number 88881.361830/2019-01).

\section{Acknoledgements}

The authors thank to Floresta Estadual José Zago admistrators for logistical support. We also appreciate the suggestions on the data from the colleagues from the Department of Geosciences and Natural Resources Management, University of Copenhagen.

Conflicts of interest/Competing interests: The authors declare no known conflict of interest.

Availability of data and material: The data that support the findings of this study are available from the corresponding author upon reasonable request.

Code availability: not applicable 
Ethics approval: not applicable

Consent to participate: not applicable

Consent for publication: not applicable

\section{References}

1. Araújo EA, Ker JC, Mendonça EDS et al (2011) Impact of forest-pasture conversion on stocks and dynamics of soil carbon and humic substances in the Amazon. Acta Amaz 41:103-114. https://doi.org/10.1590/S0044-59672011010200001

2. Barroso DG, da Silva Souza MGO, de Freitas de Oliveira TP, Siqueira DP (2018) Growth of atlantic forest trees and their influence on topsoil fertility in the Southeastern Brazil. Cerne 24:352-359. https://doi.org/10.1590/01047760201824042605

3. Bingham AH, Cotrufo MF (2016) Organic nitrogen storage in mineral soil: Implications for policy and management. Sci Total Environ 551-552:116-126. https://doi.org/10.1016/j.scitotenv.2016.02.020

4. Calderón-Peralta CV, Jiménez-Hernández J, Maldonado-Astudillo YI et al (2017) Influence of Hymenaea courbaril gum as a new additive on nixtamalized flour properties and quality of tortilla. $J$ Food Process Eng 40:. https://doi.org/10.1111/jfpe.12525

5. Callesen I, Nilsson LO, Schmidt IK et al (2013) The natural abundance of $15 \mathrm{~N}$ in litter and soil profiles under six temperate tree species: $\mathrm{N}$ cycling depends on tree species traits and site fertility. Plant Soil 368:375-392. https://doi.org/10.1007/s11104-012-1515-x

6. Campo J, Merino A (2016) Variations in soil carbon sequestration and their determinants along a precipitation gradient in seasonally dry tropical forest ecosystems. Glob Chang Biol 22:1942-1956. https://doi.org/10.1111/gcb.13244

7. Cartaxo SL, de Almeida Souza MM, de Albuquerque UP (2010) Medicinal plants with bioprospecting potential used in semi-arid northeastern Brazil. J Ethnopharmacol 131:326-342.

https://doi.org/10.1016/j.jep.2010.07.003

8. Carvalho DC, De, Pereira MG, Guareschi RF et al (2017) Carbon, Nitrogen and Natural Abundance of $\delta 13 \mathrm{C}$ in Forest Cover. Floresta e Ambient 15:47-66

9. Chaer GM, Resende AS, Campello EFC et al (2011) Nitrogen-fixing legume tree species for the reclamation of severely degraded lands in Brazil. Tree Physiol 31:139-149. https://doi.org/10.1093/treephys/tpq116

10. Conen F, Zimmermann $\mathrm{M}$, Leifeld $\mathrm{J}$ et al (2008) Relative stability of soil carbon revealed by shifts in $\delta 15 \mathrm{~N}$ and C:N ratio. Biogeosciences 5:123-128. https://doi.org/10.5194/bg-5-123-2008

11. Cotrufo MF, Wallenstein MD, Boot CM et al (2013) The Microbial Efficiency-Matrix Stabilization (MEMS) framework integrates plant litter decomposition with soil organic matter stabilization: Do labile plant inputs form stable soil organic matter? Glob Chang Biol 19:988-995. https://doi.org/10.1111/gcb.12113 
12. De Moraes JFL, Volkoff B, Cerri CC, Bernoux M (1996) Soil properties under Amazon forest and changes due to pasture installation in Rondônia, Brazil. Geoderma 70:63-81. https://doi.org/10.1016/0016-7061(95)00072-0

13. Della Torre A, Albuquerque LBL, Farrapo NM et al (2011) Mutagenicity induced by the hydroalcoholic extract of the medicinal plant plathymenia reticulata benth. J Venom Anim Toxins Incl Trop Dis 17:190-198. https://doi.org/10.1590/S1678-91992011000200010

14. Dortzbach D, Pereira MG, Blainski É, González AP (2015) Carbon stock and natural abundance of $13 \mathrm{C}$ as a function of conversion of forest and Grassland areas in Southern Brazil. Rev Bras Cienc do Solo 39:1643-1660. https://doi.org/10.1590/01000683rbcs20140531

15. Erbano M, Duarte MR (2012) Centrolobium tomentosum: microscopic diagnosis of the leaf and stem. Rev Bras Farmacogn 22:249-256

16. Forrester DI, Pares A, O'Hara C et al (2013) Soil Organic Carbon is Increased in Mixed-Species Plantations of Eucalyptus and Nitrogen-Fixing Acacia. Ecosystems 16:123-132. https://doi.org/10.1007/s10021-012-9600-9

17. Gombeau K, de Oliveira RB, Sarrazin SLF et al (2019) Protective effects of Plathymenia reticulata and Connarus favosus aqueous extracts against cadmium- and mercury-induced toxicities. Toxicol Res 35:25-35. https://doi.org/10.5487/TR.2019.35.1.025

18. Guillaume T, Damris M, Kuzyakov Y (2015) Losses of soil carbon by converting tropical forest to plantations: Erosion and decomposition estimated by $813 \mathrm{C}$. Glob Chang Biol 21:3548-3560. https://doi.org/10.1111/gcb.12907

19. Hobbie EA, Ouimette AP (2009) Controls of nitrogen isotope patterns in soil profiles. Biogeochemistry 95:355-371. https://doi.org/10.1007/s10533-009-9328-6

20. Hoogmoed M, Cunningham SC, Baker $\mathrm{P}$ et al (2014a) N-fixing trees in restoration plantings: Effects on nitrogen supply and soil microbial communities. Soil Biol Biochem 77:203-212. https://doi.org/10.1016/j.soilbio.2014.06.008

21. Hoogmoed M, Cunningham SC, Baker PJ et al (2014b) Is there more soil carbon under nitrogen-fixing trees than under non-nitrogen-fixing trees in mixed-species restoration plantings? Agric Ecosyst Environ 188:80-84. https://doi.org/10.1016/j.agee.2014.02.013

22. Houlton BZ, Sigman DM, Hedin LO (2006) Isotopic evidence for large gaseous nitrogen losses from tropical rainforests. Proc Natl Acad Sci U S A 103:8745-8750.

https://doi.org/10.1073/pnas.0510185103

23. Li J, Li M, Dong L et al (2020) Plant productivity and microbial composition drive soil carbon and nitrogen sequestrations following cropland abandonment. Sci Total Environ 744:140802. https://doi.org/10.1016/j.scitotenv.2020.140802

24. Lima AMN, Silva IR, Neves JCL et al (2006) Soil organic carbon dynamics following afforestation of degraded pastures with eucalyptus in southeastern Brazil. For Ecol Manage 235:219-231. https://doi.org/10.1016/j.foreco.2006.08.331 
25. Liu J, Zhang Z, Zhang M (2018a) Impacts of forest structure on precipitation interception and run-off generation in a semiarid region in northern China. Hydrol Process 32:2362-2376. https://doi.org/10.1002/hyp.13156

26. Liu Y, Hu C, Hu W et al (2018b) Stable isotope fractionation provides information on carbon dynamics in soil aggregates subjected to different long-term fertilization practices. Soil Tillage Res 177:54-60. https://doi.org/10.1016/j.still.2017.11.016

27. Luo Y, Su B, Currie WS et al (2004) Progressive nitrogen limitation of ecosystem responses to rising atmospheric carbon dioxide. Bioscience 54:731-739. https://doi.org/10.1641/00063568(2004)054[0731:PNLOER]2.0.C0;2

28. Macedo MO, Resende AS, Garcia PC et al (2008) Changes in soil C and N stocks and nutrient dynamics 13 years after recovery of degraded land using leguminous nitrogen-fixing trees. For Ecol Manage 255:1516-1524. https://doi.org/10.1016/j.foreco.2007.11.007

29. Maggiotto SR, de Oliveira D, Jamil Marur C et al (2014) Potencial de sequestro de carbono em seringais no noroeste do Paraná, Brasil. Acta Sci - Agron 36:239-245.

https://doi.org/10.4025/actasciagron.v36i2.17404

30. Marschner B, Brodowski S, Dreves A et al (2008) How relevant is recalcitrance for the stabilization of organic matter in soils? J Plant Nutr Soil Sci 171:91-110. https://doi.org/10.1002/jpln.200700049

31. Martinelli ALA, Piccolo MC, Townsend AR et al (1999) Nitrogen Stable Isotopic Composition of Leaves and Soil: Tropical versus Temperate Forests. Biogeochemistry 46:45-65

32. Mayer M, Prescott CE, Abaker WEA et al (2020) Influence of forest management activities on soil organic carbon stocks: A knowledge synthesis. For Ecol Manage 466:118127. https://doi.org/10.1016/j.foreco.2020.118127

33. Mendes L, Paula R, Souza P et al (2021) Nitrogen accumulated and biologically fixed by uninoculated Anadenanthera peregrina (L.) Speg trees under monospecific stands in the Atlantic Forest biome. Brazilian J Bot. https://doi.org/10.1007/s40415-021-00713-z

34. Myers N, Mittermeier R, Mittermeier $\mathrm{C}$ et al (2000) Biodiversity hotspots for conservation priorities. Nature 16:853-858. https://doi.org/10.1080/21564574.1998.9650003

35. McGill R, Tukey JW, Larsen WA (1978) Variations of boxplots. The American Statitician McGill R 32:12. doi:10.2307/2683468

36. Nave LE, Vance ED, Swanston CW, Curtis PS (2009) Impacts of elevated N inputs on north temperate forest soil $\mathrm{C}$ storage, $\mathrm{C} / \mathrm{N}$, and net $\mathrm{N}$-mineralization. Geoderma 153:231-240. https://doi.org/10.1016/j.geoderma.2009.08.012

37. Nel JA, Craine JM, Cramer MD (2018) Correspondence between $\delta 13 \mathrm{C}$ and $\delta 15 \mathrm{~N}$ in soils suggests coordinated fractionation processes for soil C and N. Plant Soil 423:257-271. https://doi.org/10.1007/s11104-017-3500-x

38. Ngaba MJY, Bol R, Hu YL (2020) Stable isotopic signatures of carbon and nitrogen in soil aggregates following the conversion of natural forests to managed plantations in eastern China. Plant Soil 371385. https://doi.org/10.1007/s11104-020-04754-3 
39. Ngaba MJY, Hu YL, Bol R et al (2019) Effects of land use change from natural forest to plantation on $\mathrm{C}, \mathrm{N}$ and natural abundance of $13 \mathrm{C}$ and $15 \mathrm{~N}$ along a climate gradient in eastern China. Sci Rep 9:112. https://doi.org/10.1038/s41598-019-52959-z

40. Oostra S, Majdi H, Olsson M (2006) Impact of tree species on soil carbon stocks and soil acidity in southern Sweden. Scand J For Res 21:364-371. https://doi.org/10.1080/02827580600950172

41. Pan Y, Birdsey RA, Fang $J$ et al (2011) A large and persistent carbon sink in the world's forests. Science 333:988-993. https://doi.org/10.1126/science.1201609

42. Paul A, Balesdent J, Hatté C (2019) 13C-14C relations reveal that soil 13C-depth gradient is linked to historical changes in vegetation 13C. Plant Soil. https://doi.org/10.1007/s11104-019-04384-4

43. Peng Y, Schmidt IK, Zheng H et al (2020) Tree species effects on topsoil carbon stock and concentration are mediated by tree species type, mycorrhizal association, and $\mathrm{N}$-fixing ability at the global scale. For Ecol Manage 478:118510. https://doi.org/10.1016/j.foreco.2020.118510

44. Peri PL, Ladd B, Pepper DA et al (2012) Carbon ( $\delta 13 C)$ and nitrogen ( $\delta 15 \mathrm{~N})$ stable isotope composition in plant and soil in Southern Patagonia's native forests. Glob Chang Biol 18:311-321. https://doi.org/10.1111/j.1365-2486.2011.02494.x

45. Core team R (2019) R: A language and environment for statistical computing. R Foundation for Statistical Computing, Vienna

46. Resh SC, Binkley D, Parrotta JA (2002) Greater soil carbon sequestration under nitrogen-fixing trees compared with Eucalyptus species. Ecosystems 5:217-231. https://doi.org/10.1007/s10021-0010067-3

47. Ribeiro MC, Metzger JP, Martensen AC et al (2009) The Brazilian Atlantic Forest: How much is left, and how is the remaining forest distributed? Implications for conservation. Biol Conserv 142:11411153. https://doi.org/10.1016/j.biocon.2009.02.021

48. Silver WL, Ostertag R, Lugo AE (2000) The potential for carbon sequestration through reforestationof abandoned tropical agricultural and pasture lands. Restor Ecol 8:394-407. https://doi.org/10.1046/j.1526-100X.2000.80054.x

49. Siqueira D, Riter Netto A, Freire J, Barroso D (2021) Natural mycorrhizal association of two tropical Nfixing monospecific plantations, Southeastern Brazil. Rhizosphere 104743. https://doi.org/10.1016/j.rhisph.2021.100377

50. Siqueira DP, Carvalho GCMW, Silva JGS, Caldeira MVW, Barroso DG in press. Litter decomposition and nutrient release of two tropical $\mathrm{N}$-fixing species, Rio de Janeiro Brazil. J. For Res

51. SOS Mata Atlântica foundation; Instituto Nacional de Pesquisas Espaciais (2020) Atlas dos remanescentes florestais da Mata Atlântica. Período 2018-2019. Relatório técnico. São Paulo

52. Stockmann U, Adams MA, Crawford JW et al (2013) The knowns, known unknowns and unknowns of sequestration of soil organic carbon. Agric Ecosyst Environ 164:80-99. https://doi.org/10.1016/j.agee.2012.10.001

53. Thomas KD, Prescott CE (2000) Nitrogen availability in forest floors of three tree species on the same site: The role of litter quality. Can J For Res 30:1698-1706. https://doi.org/10.1139/x00-101 
54. Vesterdal L, Ritter E, Gundersen $P$ (2002) Change in soil organic carbon following afforestation of former arable land. For Ecol Manage 169:137-147. https://doi.org/10.1016/S0378-1127(02)003043

55. Vesterdal L, Schmidt IK, Callesen I et al (2008) Carbon and nitrogen in forest floor and mineral soil under six common European tree species. For Ecol Manage 255:35-48. https://doi.org/10.1016/j.foreco.2007.08.015

56. Vicente LC, Gama-Rodrigues EF, Gama-Rodrigues AC (2016) Soil carbon stocks of Ultisols under different land use in the Atlantic rainforest zone of Brazil. Geoderma Reg 7:330-337. https://doi.org/10.1016/j.geodrs.2016.06.003

57. Villela D, de Mattos E, Pinto A et al (2012) Carbon and nitrogen stock and fluxes in coastal Atlantic Forest of southeast Brazil: potential impacts of climate change on biogeochemical functioning. Brazilian J Biol 72:633-642. https://doi.org/10.1590/s1519-69842012000400003

58. Vu QV (2011) ggbiplot: a ggplot2 based biplot. R package version 0.55

59. Wang F, Li Z, Xia H et al (2010) Effects of nitrogen-fixing and non-nitrogen-fixing tree species on soil properties and nitrogen transformation during forest restoration in southern China. Soil Sci Plant Nutr 56:297-306. https://doi.org/10.1111/j.1747-0765.2010.00454.x

60. Xiang Y, Liu Y, Yue X et al (2021) Factors controlling soil organic carbon and total nitrogen stocks following afforestation with Robinia pseudoacacia on cropland across China. For Ecol Manage 494:119274. https://doi.org/10.1016/j.foreco.2021.119274

61. Xu S, Sayer EJ, Eisenhauer $\mathrm{N}$ et al (2021) Aboveground litter inputs determine carbon storage across soil profiles: a meta-analysis. Plant Soil 429-444. https://doi.org/10.1007/s11104-021-04881-5

62. Zheng Y, Hu Z, Pan X et al (2021) Carbon and nitrogen transfer from litter to soil is higher than rapid decomposing plant litter: A synthesis of stable isotope studies. Soil Biol Biochem 108196. https://doi.org/10.1016/j.soilbio.2021.108196

\section{Figures}



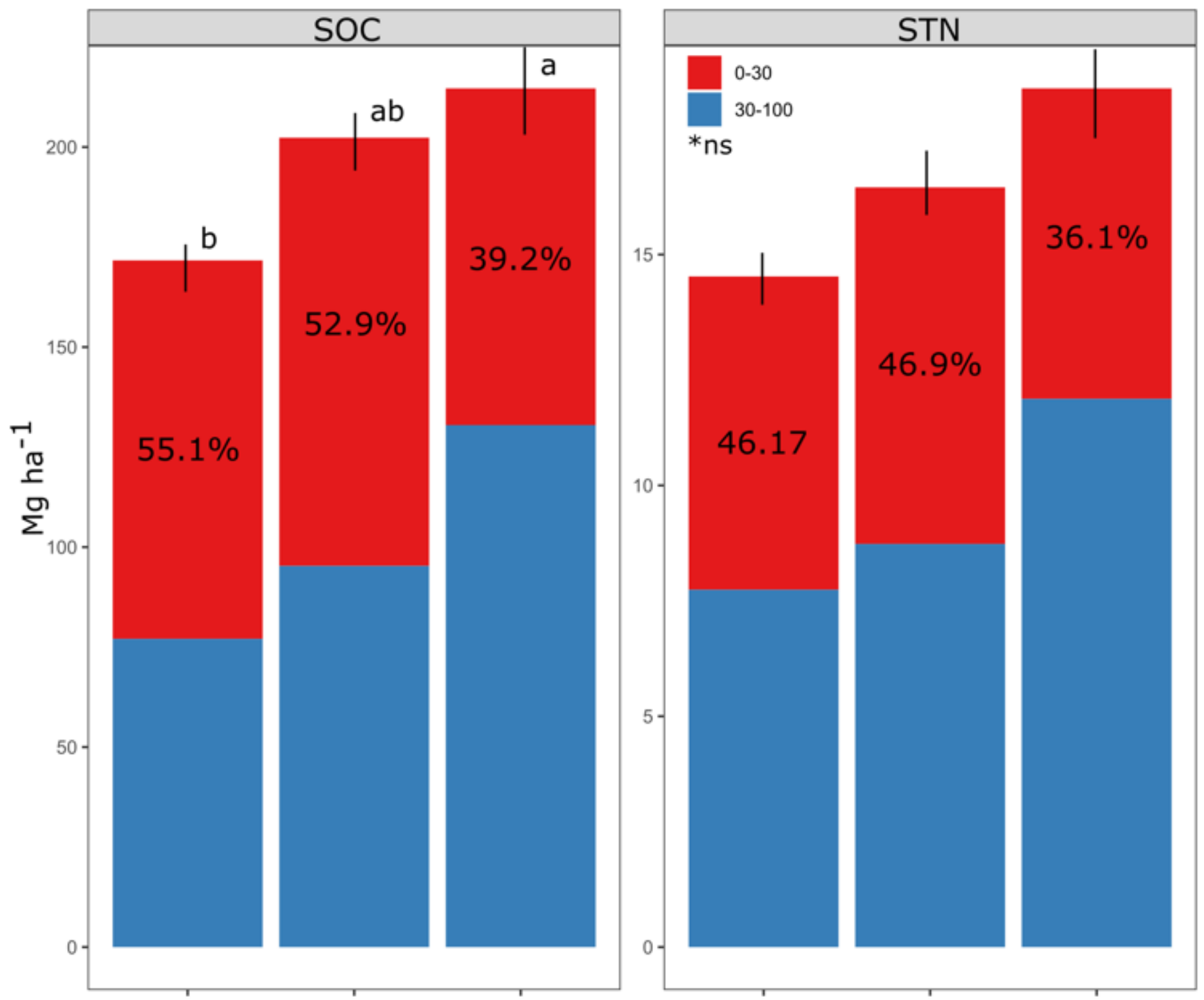

C. tomentosum $H$. courbaril $P$. reticulata

C. tomentosum H. courbaril P. reticulata

\section{Figure 1}

Soil organic carbon (SOC) and total nitrogen (STN) stocks in 0-100 cm soil layer beneath N-fixing plantations in the Southeast Brazil; Vertical bars represent \pm standard deviation. Means followed by different lowercase letters differed statistically by Confidence Interval $(p<0.05)$. ${ }^{*} n s$ - not significantly different $(p>0.05)$. 

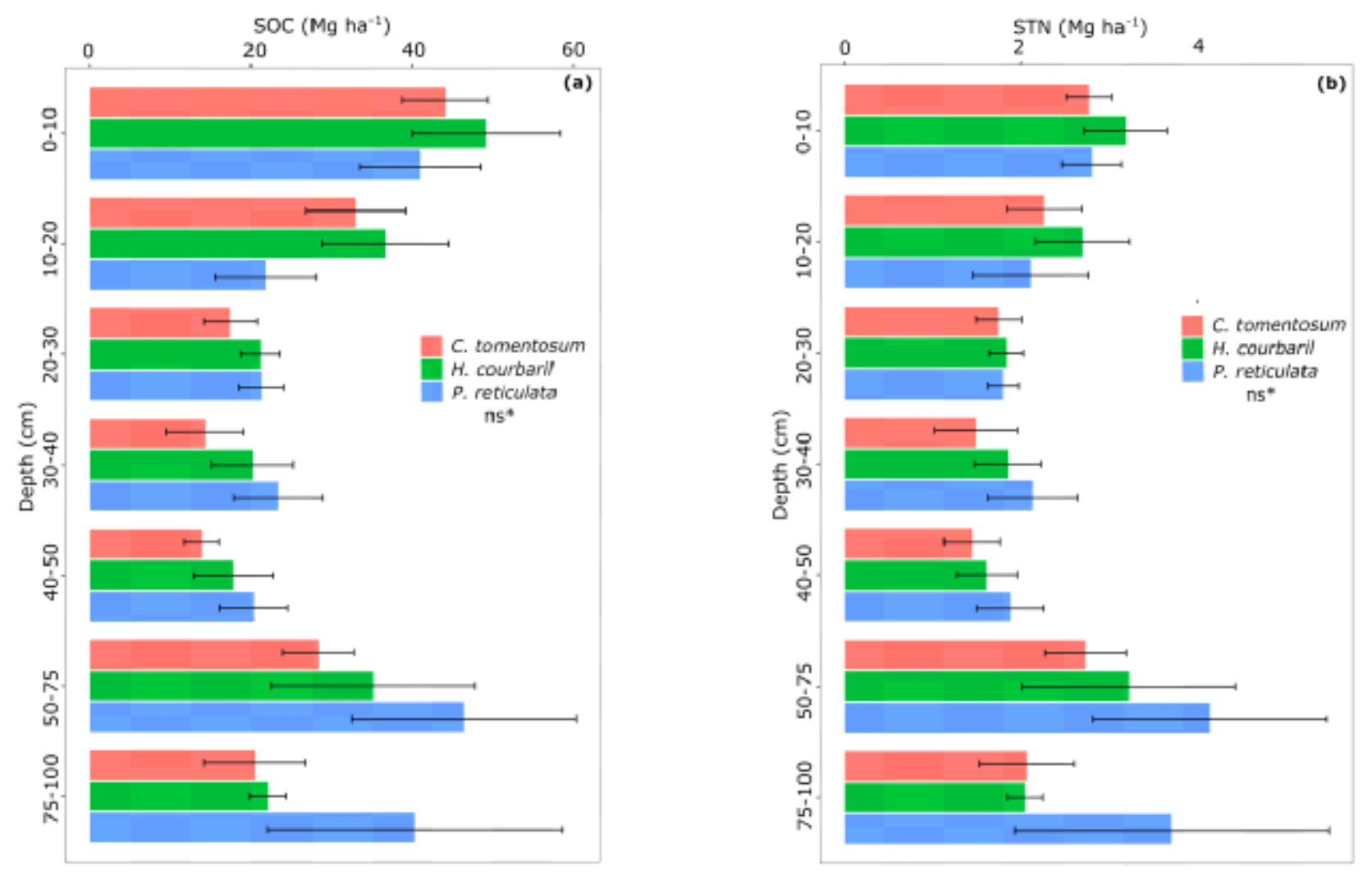

Figure 2

Soil organic carbon (SOC) and total nitrogen (STN) stocks at the individual layers beneath $\mathrm{N}$-fixing plantations in the Southeast Brazil; Vertical bars represent \pm standard deviation. *ns - means not significantly different $(p>0.05)$.
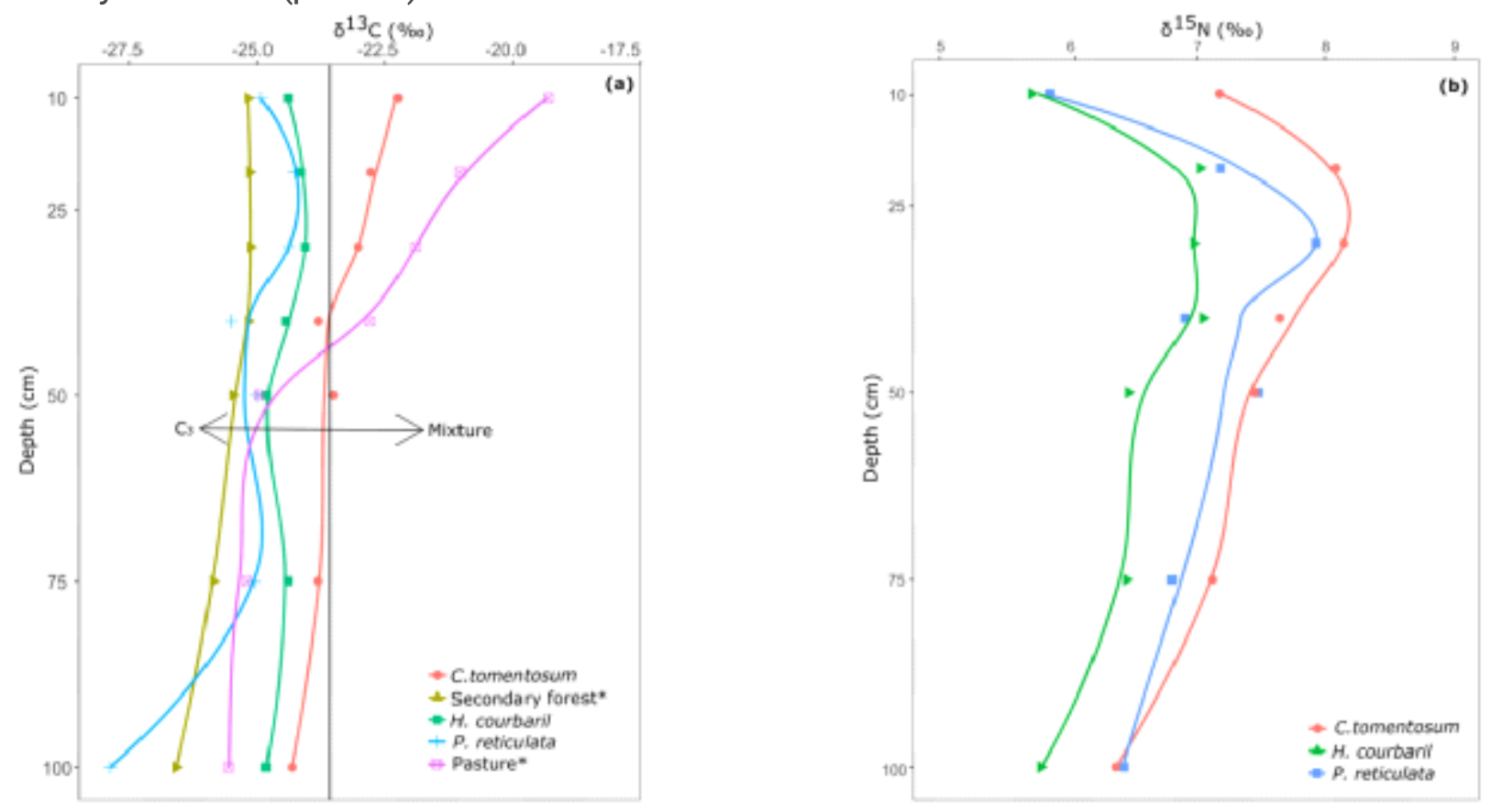

Figure 3 
Changes in $\delta 13 \mathrm{C}$ values (a) and $\delta 15 \mathrm{~N}$ values (b) in the soil profile beneath $\mathrm{N}$-fixing plantations in the Southeast Brazil. *Secondary forest and pasture $\delta 13 C$ data are from Vicente et al. (2016).
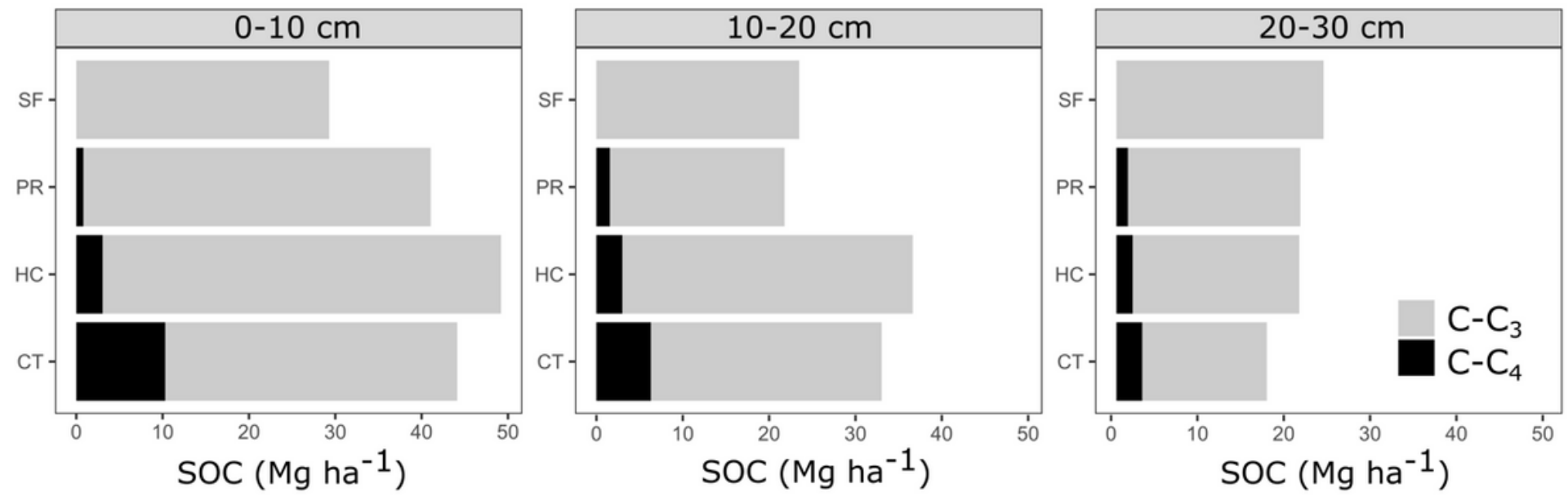

Figure 4

Soil organic carbon divided into C3 plants (tree)-derived and C4 plants (pasture)-derived in the 0-30 cm soil layer beneath different tropical $\mathrm{N}$-fixing tree plantations and the Secondary Forest (SF) from Vicente et al., (2016); PR - Plathymenia reticulata; HC - Hymenaea courbaril; CT - Centrolobium tomentosum. 


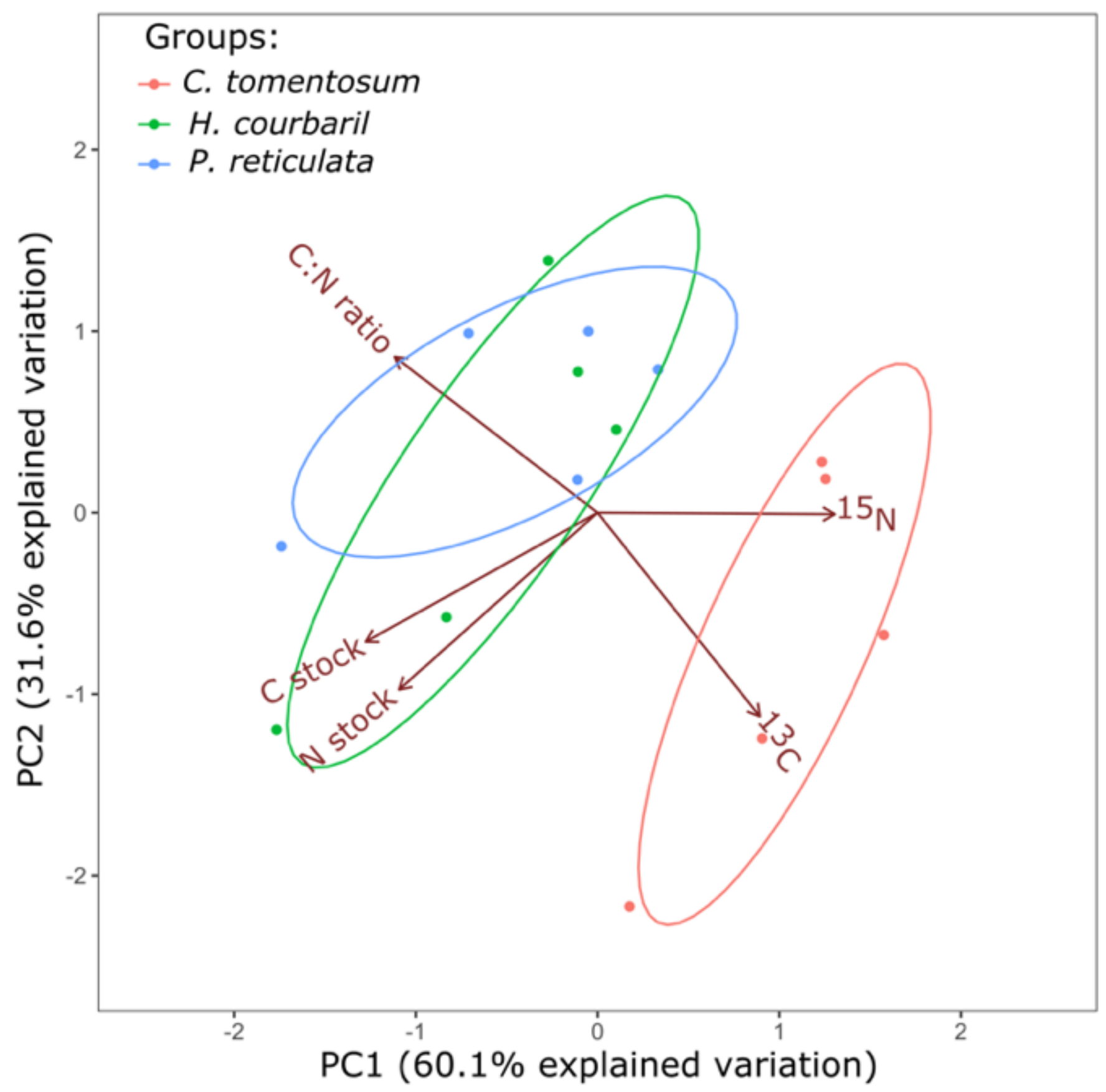

Figure 5

Principal component analysis of soil variables comprising combined 0-30 cm soil layers. The area of the ellipses was determined according to the normal distribution. $15 \mathrm{~N}$ - natural abundance of $615 \mathrm{~N}$ values in the soil; $13 \mathrm{C}$ - natural abundance of $\delta 13 \mathrm{C}$ values in the soil; $\mathrm{C}$ stock - Soil organic carbon stock; N stock - Soil total nitrogen stock; $\mathrm{C}: \mathrm{N}$ ratio - Carbon: nitrogen ratio.

\section{Supplementary Files}

This is a list of supplementary files associated with this preprint. Click to download. 
- Supplementarymaterial.docx

Page 22/22 